\title{
Diagnostics and treatment of acromegaly - updated recommendations of the Polish Society of Endocrinology
}

\author{
Marek Bolanowski ${ }^{1}$, Marek Ruchała ${ }^{2}$, Wojciech Zgliczyński ${ }^{3}$, Beata Kos-Kudła ${ }^{4}$, \\ Alicja Hubalewska-Dydejczyk ${ }^{5}$, Andrzej Lewiński ${ }^{6}$ \\ ${ }^{1}$ Department of Endocrinology, Diabetes and Isotope Therapy, Medical University Wroclaw, Poland \\ ${ }^{2}$ Department of Endocrinology, Metabolism and Internal Medicine, University of Medical Sciences, Poznan, Poland \\ ${ }^{3}$ Department of Endocrinology, The Centre of Postgraduate Medical Education, Warsaw, Poland \\ ${ }^{4}$ Division of Endocrinology, Department of Pathophysiology and Endocrinology, Medical University of Silesia, Katowice, Poland \\ ${ }^{5}$ Department of Endocrinology, Jagiellonian University Collegium Medicum, Kraków, Poland \\ ${ }^{6}$ Department of Endocrinology and Metabolic Disorders, Medical University, Lodz, Poland
}

\begin{abstract}
Acromegaly is a rare disease caused by excessive production of growth hormone (GH), typically by a pituitary tumour. The diagnosis is usually delayed, and patients frequently develop various complications that cause premature mortality. In patients with hypertension, heart failure, diabetes, and arthropathies that are not age-specific, attention should be paid to signs of acromegaly. Insulin-like growth factor 1 (IGF-1) assay should be used as a screening test whenever acromegaly is suspected. Further diagnostic investigations and treatment should be carried out at specialist centres. First-line treatment involves selective excision of pituitary adenoma using transsphenoidal access. Patients with chances of cure with surgical removal of the pituitary tumour should be referred to centres that have experience in this type of procedure, following pharmacological preparation. Other patients, as well as patients after failed neurosurgical treatment, should first receive chronic treatment with first-generation somatostatin analogues. For second-line treatment, pasireotide, pegvisomant, cabergoline, or combinations thereof should be considered. In every case, acromegaly sequelae require life-long monitoring and active treatment. Current recommendations, being an updated version of the recommendations published in Endokrynologia Polska in 2014, which take into account the Polish situation, should prove useful in the management of patients with acromegaly. (Endokrynol Pol 2019; 70 (1): 2-10)

Key words: acromegaly; diagnostics; treatment; recommendations
\end{abstract}

\section{Introduction}

Polish proposals concerning diagnostic and therapeutic management of patients with acromegaly were first published in 2014 [1]. They referred to the ongoing changes in the criteria of diagnosis, cure, and pharmacological control of the disease, as well as new therapeutic options $[2,3]$. They also paid special attention to the development of acromegaly complications that adversely affect the patients' survival and quality of life [4]. Since then, we have witnessed further advances in diagnostic investigations and an increase in the availability of various pharmacotherapies. Hence the need for a recommendation update and adjustment to new treatment options, which would take into account the country-specific situation $[5,6]$.

\section{Disease characteristics}

Acromegaly is a rare chronic disease caused by excessive production of growth hormone $(\mathrm{GH})$, typically by a pituitary tumour. It leads to changes in the patient's appearance - acral enlargement (hands, feet, and face), hypertrophy of the soft tissues, bones, and internal organs, as well as a number of systemic complications that reduce the patient's quality of life and survival [7-9]. Signs and symptoms of acromegaly are listed in Table I [1].

\section{Epidemiology}

The prevalence of acromegaly is estimated at approximately 70 cases per million inhabitants. Every year about 3-4 new cases per million inhabitants are reported. The number of Polish patients is expected to reach up to 3000 . In both males and females acromegaly is diagnosed with roughly the same frequency, typically in their 30s-50s. The disease is usually diagnosed only 5-10 years after the onset of first signs and symptoms, typically earlier in females [7-11]. Detailed population-based studies conducted in recent years suggest that acromegaly is more prevalent 
Table I. Clinical signs and symptoms of acromegaly [1]

\begin{tabular}{|c|c|}
\hline \multirow[t]{8}{*}{$\begin{array}{l}\text { General } \\
\text { symptoms }\end{array}$} & $\begin{array}{l}\text { Enlargement of: hands, feet, facial bones (nose, } \\
\text { mandible, frontal sinuses), tongue }\end{array}$ \\
\hline & Thickened facial features \\
\hline & Soft tissue swelling \\
\hline & Enlargement of internal organs (visceromegaly) \\
\hline & Weight gain \\
\hline & Increased sweating \\
\hline & Hirsutism \\
\hline & Change in voice tone \\
\hline \multirow{3}{*}{$\begin{array}{l}\text { Circulatory } \\
\text { system }\end{array}$} & Arterial hypertension \\
\hline & Dyspnea, swelling (heart failure) \\
\hline & Cardiac dysrhythmia \\
\hline \multirow{2}{*}{$\begin{array}{l}\text { Respiratory } \\
\text { system }\end{array}$} & Obstructive sleep apnoea, snoring \\
\hline & Impaired patency of the upper respiratory tract \\
\hline \multirow{4}{*}{$\begin{array}{l}\text { Endocrine } \\
\text { system }\end{array}$} & Glucose intolerance, diabetes mellitus \\
\hline & Goitre, thyroid dysfunction \\
\hline & Galactorrhoea \\
\hline & Possible tumours of other glands (MEN syndrome) \\
\hline \multirow[t]{2}{*}{$\begin{array}{l}\text { Digestive } \\
\text { system }\end{array}$} & $\begin{array}{l}\text { Constipation, possible elongation and widening of } \\
\text { the colon (megacolon) }\end{array}$ \\
\hline & $\begin{array}{l}\text { Abdominal pain, blood in faeces (polyps and } \\
\text { colonic diverticula) }\end{array}$ \\
\hline \multirow{4}{*}{$\begin{array}{l}\text { Genitourinary } \\
\text { system }\end{array}$} & Menstrual disorders \\
\hline & Reduced libido \\
\hline & Erectile dysfunction (hypogonadism) \\
\hline & $\begin{array}{l}\text { Renal colic (hypercalciuria, hyperparathyroidism } \\
\text { - MEN) }\end{array}$ \\
\hline \multirow{3}{*}{$\begin{array}{l}\text { Nervous } \\
\text { system }\end{array}$} & Headache \\
\hline & $\begin{array}{l}\text { Visual field impairment (macroadenoma may } \\
\text { compress the optic chiasm) }\end{array}$ \\
\hline & Paresthesias, pareses (carpal tunnel syndrome) \\
\hline \multirow{2}{*}{$\begin{array}{l}\text { Osteoarticular } \\
\text { system }\end{array}$} & Bone and joint pain and deformities \\
\hline & Limited joint mobility \\
\hline
\end{tabular}

than previously thought [12]. Therefore, one should actively look out for the disease, particularly in males and individuals suffering from cardiovascular and osteoarticular disorders that are not age-specific [1]. Early diagnosis enables surgical treatment and cure and offers a chance of restoring life expectancy similar to that of the general population as well as improving the quality of life.

\section{Pathogenesis}

GH-secreting pituitary tumours (somatotropinomas), which cause acromegaly, are benign adenomas. They occur sporadically (only 5-7\% of tumours result from germline mutation) and may run in families as familial isolated pituitary adenoma (FIPA), type 1 and type 4 multiple endocrine neoplasia (MEN), Carney complex, pituitary adenoma with pheochromocytoma/paraganglioma (3PAs) or X-linked acrogigantism [13]. However,
Table II. Complications in acromegaly [1]

\begin{tabular}{|c|c|}
\hline \multirow{8}{*}{$\begin{array}{l}\text { Cardiovascular } \\
\text { diseases }\end{array}$} & Hypertension (up to $60 \%$ ) \\
\hline & Cardiac hypertrophy (up to $90 \%$ ) \\
\hline & Cardiac dysrhythmia (up to $40 \%$ ) \\
\hline & Heart valve defects (up to $80 \%$ ) \\
\hline & Heart failure (up to $10 \%$ ) \\
\hline & Ischaemic heart disease (up to $40 \%$ ) \\
\hline & Sudden cardiac death \\
\hline & Cerebral stroke \\
\hline \multirow{4}{*}{$\begin{array}{l}\text { Respiratory } \\
\text { diseases }\end{array}$} & Obstructive sleep apnoea (up to 80\%) \\
\hline & Obturation of the upper respiratory tract \\
\hline & Bronchiectasis \\
\hline & Emphysema \\
\hline \multirow[t]{2}{*}{ Neoplasms } & $\begin{array}{l}\text { Malignant - colon }(2 \%) \text {, thyroid }(5 \%) \text {, breast } \\
\text { and prostate cancers }\end{array}$ \\
\hline & $\begin{array}{l}\text { Benign - thyroid tumours (up to } 90 \% \text { ), colonic } \\
\text { polyps, uterine fibroids, benign prostatic } \\
\text { hyperplasia }\end{array}$ \\
\hline \multirow{7}{*}{$\begin{array}{l}\text { Metabolic } \\
\text { and hormonal } \\
\text { disorders }\end{array}$} & Hyperinsulinaemia (up to $80 \%$ ) \\
\hline & Prediabetes (up to $40 \%$ ) \\
\hline & Diabetes (up to $20 \%$ ) \\
\hline & Hyperlipidaemia \\
\hline & Hypercalciuria (up to $70 \%$ ) \\
\hline & Hypogonadism (up to $50 \%$ ) \\
\hline & Hyperthyroidism (up to $15 \%$ ) \\
\hline \multirow{3}{*}{$\begin{array}{l}\text { Diseases of the } \\
\text { osteoarticular } \\
\text { system }\end{array}$} & Degenerative and proliferative changes (up to $70 \%$ ) \\
\hline & Reduced bone mineral density (osteoporosis) \\
\hline & Vertebral fractures \\
\hline \multirow{3}{*}{$\begin{array}{l}\text { Diseases of the } \\
\text { nervous system }\end{array}$} & Visual field disturbances \\
\hline & Neuropathies \\
\hline & Carpal tunnel syndrome (up to $50 \%$ ) \\
\hline
\end{tabular}

in young individuals the rates of mutations are much higher and reach $25 \%$, leading to the development of invasive adenomas refractory to pharmacological treatment and requiring more aggressive management [14]. Genetic testing should be considered, particularly in young patients.

At diagnosis, the diameter of tumours usually exceeds $10 \mathrm{~mm}$, so they are already macroadenomas, which may cause visual field defects and other endocrine disorders (such as hypopituitarism or hyperprolactinaemia). Most of the disease signs and symptoms as well as complications (Tab. I, II) result from increased activity of insulin-like growth factor 1 (IGF-1) in tissues, stimulated by increased production of GH $[7,8]$. As a rule, the severity of clinical symptoms and systemic complications as well as $\mathrm{GH}$ concentration are positively correlated with the tumour size and acromegaly persistence. Long duration of undiagnosed and untreated disease contributes to the severity of clinical symptoms as well as the development of metabolic sequelae and systemic complications, thus reducing the chances of full recovery. 


\section{Diagnostics}

The diagnosis of active acromegaly is based on the presence of signs and symptoms (Tab. I) and increased secretion of both IGF-1 and GH. Patients with signs suggestive of acromegaly should undergo a screening IGF-1 assay (Fig. 1) [1]. If the levels are above the upper limit of normal (for age and sex), GH suppression in oral glucose tolerance test (OGTT) after administration of $75 \mathrm{~g}$ of glucose is recommended. In patients with established diabetes, $\mathrm{GH}$ concentration should be determined instead, e.g. every 30 minutes over a period of $2-3$ hours. Active acromegaly is diagnosed when the IGF-1 level is increased and GH secretion in OGTT is not suppressed below 1.0 $\mu \mathrm{g} / \mathrm{L}(\mathrm{ng} / \mathrm{mL})$, or $0.4 \mu \mathrm{g} / \mathrm{L}$ in the case of ultrasensitive $\mathrm{GH}$ assay $[1,5,6,15]$. A random GH level below $1.0 \mu \mathrm{g} / \mathrm{L}$ rules out active acromegaly [2,3]. The GH level in OGTT may depend on the patient's age, BMI, sex, and the use of oestrogens, which should be taken into account in the interpretation of test results. One should also bear in mind that false positive results of the GH test may be related to puberty, malnutrition, use of oral oestrogens, renal or hepatic insufficiency, and hyperthyroidism. In the case of puberty and hyperthyroidism the IGF-1 test results may also be false positive. At diagnosis, assessment of the presence and severity of systemic complications, metabolic disorders, and hormonal dysfunctions related to the pituitary tumour should be carried out (Tab. II) [1].

In order to identify the cause of acromegaly magnetic resonance imaging (with contrast enhancement) of the sella turcica region is necessary. If pituitary macroadenoma has been found, the visual field needs to be assessed. Failure to visualise a pituitary tumour by MRI should raise a suspicion of ectopic secretion of somatoliberin (GHRH) or, less frequently, GH by a neuroendocrine tumour, usually located in the bronchi, thymus, or pancreas [5]. MRI of a pituitary tumour should also involve assessment of T2-weighted signal intensity relative to the brain. Hypointensity of the adenoma signal is related to its densely granulated structure, lower invasiveness, and higher density of type 2 somatostatin receptors, which is associated with higher effectiveness of first-generation somatostatin analogues in reducing adenoma volume and normalising hormone levels [16].

Early diagnosis of acromegaly (a smaller tumour, less severe symptoms and complications) translates into increased effectiveness of treatment (both surgical and pharmacological), reduced healthcare costs, and probable prevention of premature death.

\section{Treatment}

The main goal of acromegaly treatment it to normalise the GH and IGF-1 secretion and thus improve life expectancy and quality of life. Tumour removal or significant reduction in its volume, which should reduce symptoms related to its expansion, is the secondary goal. Both goals can be achieved with surgical treatment, pharmacotherapy, or, less frequently, radiotherapy $[5,8,17]$.

When selecting a treatment option, one should assess possible complications as well as the patient's health status and preferences. The treatment of choice that may achieve cure involves selective surgical removal of pituitary adenoma, using a transsphenoidal approach if feasible, while hormonal function of the residual gland is preserved. In the case of extrapituitary source of disease, removal of the neuroendocrine tumour responsible for ectopic GHRH secretion is used. The effectiveness and success of surgical treatment of somatotropic pituitary tumours depend on GH concentration, tumour size, location, and expansion, and the surgeon's experience. In the case of microadenomas, surgical success $(\mathrm{GH}<1.0 \mu \mathrm{g} / \mathrm{L})$ is achieved in approximately $70-90 \%$ of patients, while in the case of macroadenomas - only in about 30-50\% [17].

Thus, larger tumours with additionally extrasellar expansion are associated with lower effectiveness of neurosurgery. Therefore, in accordance with the recommendations of the Polish Society of Endocrinology, one should consider the need for preoperative administration of long-acting somatostatin analogues, which facilitate surgical treatment by reducing the volume and changing the consistency of the pituitary tumour, and bring clinical improvement [18]. Such treatment reduces the swelling of the soft tissues (making intubation easier) and improves cardiovascular function (by lowering blood pressure and reducing heart failure severity), obstructive sleep apnoea, and the levels of metabolic disorders markers [19]. However, it should not delay surgery but should be used as preparation to surgery. Better surgery outcomes are achieved in centres where neurosurgeons perform at least 50 transsphenoidal surgeries a year, which is why appropriately prepared patients should be referred to centres specialising in this type of procedure $[5,20]$.

Since most tumours found when acromegaly is diagnosed are macroadenomas, surgical treatment usually does not ensure complete cure in a large proportion of patients. If this is the case, pharmacotherapy or, less frequently, radiotherapy is recommended. Removal of over $75 \%$ of the tumour mass translates into increased effectiveness of postoperative treatment with somatostatin analogues [21]. Pharmacotherapy constitutes an alternative or adjuvant treatment option for somatotropic pituitary adenomas. These adenomas express somatostatin receptors, which is why ligands for this receptor - somatostatin analogues (lanreotide 


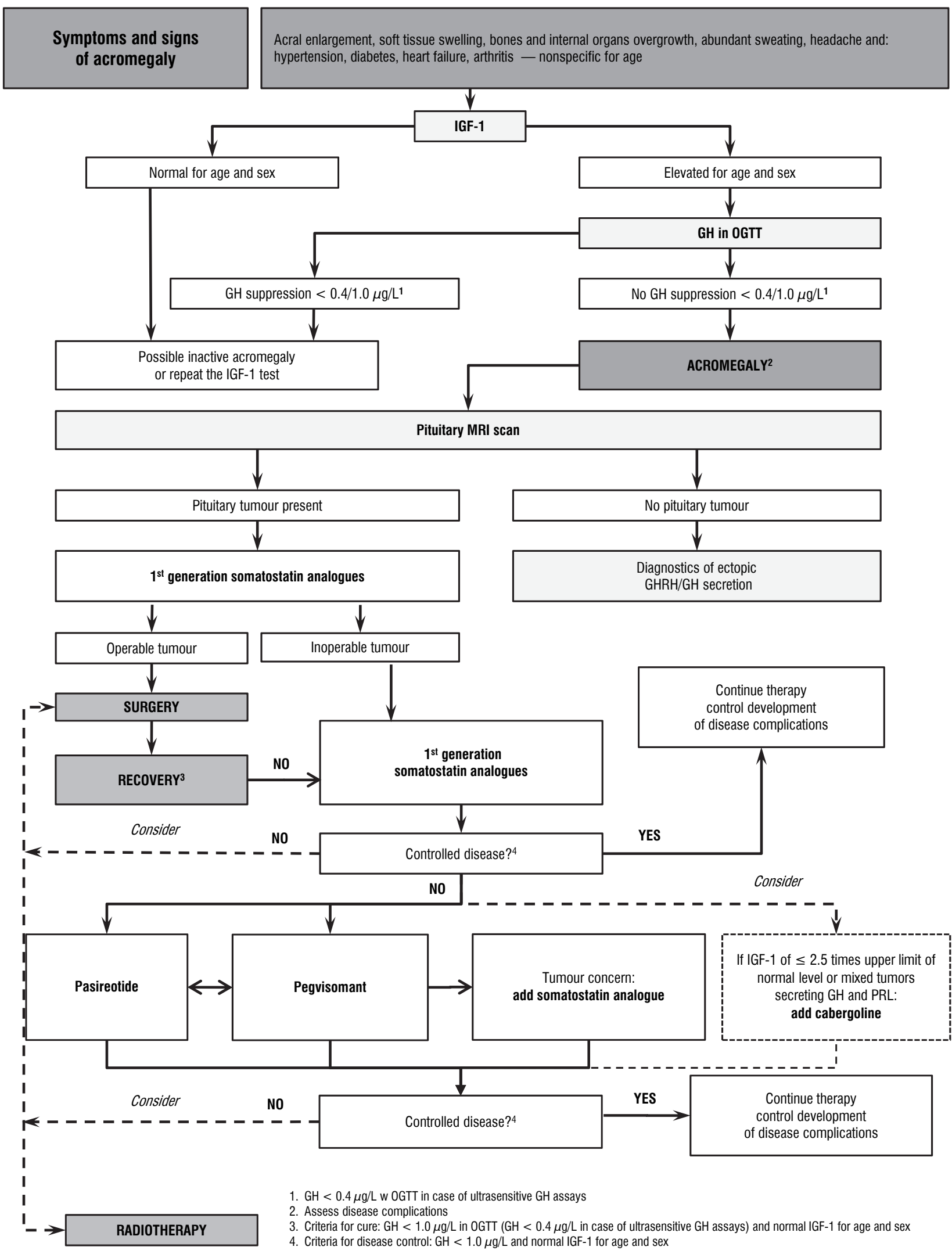

Figure 1. Treatment algorithm for acromegaly. IGF-1 — insulin-like growth factor 1; GH - growth hormone; OGTT — oral glucose tolerance test; GHRH - growth hormone-releasing hormone; PRL — prolactin 
and octreotide) - normalise GH secretion in less than $50 \%$ patients with acromegaly, and in about half they significantly reduce the tumour size $[5,8]$.

In Poland, two first-generation, long-acting somatostatin analogues are currently available for first-line treatment. Lanreotide Autogel is available in $60 \mathrm{mg}$, $90 \mathrm{mg}$, and $120 \mathrm{mg}$ ampoules for subcutaneous administration every 28 days, with an option of the dosing interval extension to 56 days in the case of the $120 \mathrm{mg}$ dosage $[1,11,22]$. Octreotide LAR is available in $10 \mathrm{mg}$, $20 \mathrm{mg}$, and $30 \mathrm{mg}$ ampoules for intramuscular administration every 28 days, with an option of dosage increase to $40 \mathrm{mg}$ every four weeks if the $30 \mathrm{mg}$ dose proves ineffective [23]. The dose of somatostatin analogue should be adjusted to clinical and laboratory outcomes after three months of use [5]. There are no significant differences in the effectiveness and tolerability between these products [24]. The treatment is safe and generally well tolerated. The most common adverse reactions are abdominal pain, loose stools, and diarrhoea. Approximately $20 \%$ of the treated individuals may develop cholelithiasis, and very rare cases of pancreatitis have also been reported [11].

Somatostatin analogues, as has already been mentioned, should be used for several months as part of preparation for surgical treatment and as long-term treatment if surgery was not performed or proved ineffective. This should be the treatment of choice in individuals with significant contraindications, those who refuse surgery, or those who have little chance of cure or clinical improvement with neurosurgery (large tumours with suprasellar extension, without significant optic nerve compression) [5].

Patients with active acromegaly, after unsuccessful surgery for pituitary adenoma or awaiting the effects of adjuvant radiotherapy, should receive long-acting somatostatin analogues at doses that ensure normalisation of the GH and IGF-1 levels [3, 5, 17]. The option of using lanreotide autogel $120 \mathrm{mg}$ less than once a month (even every 56 days) significantly reduces treatment costs and at the same time increases the patient's comfort and quality of life [11, 22, 25, 26].

Factors affecting the effectiveness of first-generation somatostatin analogues include sex (better response in females), age at diagnosis (younger individuals tend to have more aggressive tumours), disease duration, adenoma size, and GH secretion [27].

If a first-generation somatostatin analogue proves ineffective, second-line treatment should include a new generation somatostatin analogue with higher affinity to type 5 somatostatin receptors (pasireotide — available under a therapeutic programme) or GH receptor antagonist (pegvisomant - reimbursement under a therapeutic programme is being considered). Add- ing pegvisomant once or twice weekly or a dopamine agonist to a first-generation somatostatin analogue is another option (Fig. 1) [2, 3, 5, 17].

Pasireotide is more potent than first-generation somatostatin analogues. It reduces the tumour volume and achieves biochemical control or further significant suppression of the GH and IGF-1 levels in a greater percentage of patients. However, it has diabetogenic effects [27-31]. Both before and during treatment with pasireotide carbohydrate metabolism should be monitored. Pasireotide is recommended if no biochemical control has been achieved, primarily in patients at risk of tumour growth, without uncontrolled carbohydrate metabolism disorders. Long-acting pasireotide is administered intramuscularly at $20 \mathrm{mg}, 40 \mathrm{mg}$, or $60 \mathrm{mg}$ every four weeks [27-31]. For the first three months after pasireotide initiation, blood glucose levels should be determined once weekly. After the dose has been increased, similar monitoring is required for 4-6 weeks. Pegvisomant or cabergoline, on the other hand, may be indicated in patients with small pituitary tumours or tumours that were not visualised in MRI, with uncontrolled diabetes (Fig. 1) [2, 3, 5].

Pegvisomant, which blocks GH activity in target tissues, normalises IGF-1 levels in over $70 \%$ of patients, achieving clinical improvement and correction of metabolic disturbances (e.g. by increasing insulin sensitivity, it improves carbohydrate metabolism) [32, 33]. Given its peripheral action, $\mathrm{GH}$ concentration cannot serve to assess the drug effectiveness - IGF-1 level is the only measure. Pegvisomant does not have a beneficial effect on the pituitary tumour size, and due to the risk of adenoma growth during treatment, tumour volume should be assessed by MRI. If the adenoma grows, a somatostatin analogue can be used [34]. Pegvisomant is administered subcutaneously on a daily basis at $10-30 \mathrm{mg}$ as monotherapy or in combination with a somatostatin analogue [32, 34, 35].

The effectiveness of dopamine agonists in the treatment of acromegaly is reduced. In acromegaly, the recommended doses should be higher than the ones used in prolactin (PRL)-producing pituitary adenoma - prolactinoma [5,36]. Bromocriptine, which is available in Poland, normalises IGF-1 concentration only in $10 \%$ of patients with acromegaly and should not be used for treatment of this disease [37]. Cabergoline, which is more expensive (not reimbursed), normalises IGF- 1 concentration in about $35 \%$ of patients. The greatest benefit is gained by individuals with mixed tumours that secrete both GH and PRL. Cabergoline used in combination with somatostatin analogues improves their effectiveness in patients resistant to maximum doses of somatostatin analogues [36, 37]. Cabergoline 
is recommended for use in patients with IGF-1 levels below 2.5-fold of the upper limit of normal [5].

Temozolomide can be used for the treatment of very aggressive tumours refractory to all of the aforementioned therapies or malignant tumours $[5,38]$.

Thanks to increasingly good outcomes of surgical treatment and the availability of effective drugs, radiotherapy is used as a third-line treatment [39, 40]. Stereotactic radiotherapy should be considered if surgical or pharmacological treatment has proved ineffective, bearing in mind that it achieves normalisation of IGF-1 concentration within 10 years only in about $40 \%$ of patients and may be associated with complications, the most common being hypopituitarism (in about $80 \%$ of individuals subjected to conventional radiotherapy). Radiation-induced damage to optic nerves, cerebral circulatory disorders, and the formation of secondary neoplasms are much less common.

Treatment of acromegaly complications constitutes an additional problem. These include primarily hypertension, heart failure, carbohydrate metabolism disorders, and degenerative/proliferative changes in the skeletal system (other complications are listed in Tab. II) $[1,4]$. These conditions result in worsened quality of life and decreased survival, and treatment thereof generates considerable additional costs. Early diagnosis of acromegaly offers a chance of successful surgical treatment, reducing to a minimum the risk of complications and thereby the costs of treatment.

Interdisciplinary specialist centres (Pituitary Tumours Centres of Excellence) are needed, where cutting edge and effective treatment options could be offered to patients with pituitary tumours, including acromegaly [41].

\section{Follow-up of patients}

Every patient with acromegaly requires follow-up involving evaluation of treatment effectiveness and monitoring of the course of disease complications based on clinical assessment, laboratory tests, and imaging examinations. Effectiveness of surgical treatment can be assessed by GH assay shortly (one week) after the procedure, while reliable assessment of IGF-1 concentration should be made only after about three months. IGF-1 concentration within sex- and age-adjusted reference values and GH below $1.0 \mu \mathrm{g} / \mathrm{L}$ (or $<0.4 \mu \mathrm{g} / \mathrm{L}$ ) in OGTT are the criteria of cure $[1,2,5]$. In long-term monitoring, using the same laboratory sets is substantiated [5]. If laboratory tests confirm cure with surgical treatment and no clinical vision disorders or pituitary dysfunctions are present, MRI is not required.

In patients who failed to achieve cure with surgery, MRI of the sella turcica region should be
Table III. Evaluation of the course of complications in acromegaly [1]

\begin{tabular}{ll}
\hline Examination & Frequency of evaluation \\
\hline Blood pressure & $\begin{array}{l}\text { Every 3-6 months, more frequently } \\
\text { when treatment is changed }\end{array}$ \\
\hline ECG & Every year \\
\hline Exercise ECG & In the case of stenocardial symptoms \\
\hline Echocardiography & Every year \\
\hline Polysomnography & Every year \\
\hline OGTT & In the case of suspicion of diabetes \\
& mellitus \\
\hline Fasting glucose & Every 6-12 months \\
\hline HbA ${ }_{1 c}$ & Every 6-12 months in the case \\
& of diabetes \\
\hline Lipid profile & Every year \\
\hline Ca, P & In the case of symptoms \\
& of nephrolithiasis \\
\hline TSH, fT4 & Every year \\
\hline PRL, testosterone (male) & Every year \\
\hline PRL, LH, FSH, E2 (female) & Every year \\
\hline Thyroid ultrasound & Every 1-2 years \\
\hline Colonoscopy & Every 2-3 years \\
\hline DXA (in hypogonadism) & Every 2-3 years \\
\hline
\end{tabular}

ECG - electrocardiography; OGTT— oral glucose tolerance test;

$\mathrm{HbA}$ - glycated hemoglobin, $\mathrm{Ca}$ - calcium; $\mathrm{P}$ - phosphorus, TSH — thyroid-stimulating hormone; fT4 — free thyroxine; PRL — prolactin; $\mathrm{LH}$ — luteinizing hormone; FSH — follicle-stimulating hormone; E2 — estradiol; DXA — dual-energy X-ray absorptiometry

performed 3-4 months after the procedure, while in patients subjected to pharmacotherapy this should be done 6-12 months after its initiation. Follow-up MRI should be performed once a year (except in patients with fast-growing tumours). When evaluating pharmacotherapy effectiveness, one should take into account the patient's clinical status (including the visual field and quality of life assessment) as well as results of random IGF-1 and GH assays (OGTT is not required). It is assumed that effective pharmacotherapy (which controls the course of disease) maintains IGF-1 concentration within sex- and age-adjusted reference values and GH below 1.0 $\mu \mathrm{g} / \mathrm{L}[1,2,5]$. From the clinical point of view, disease complications (Tab. II) should be identified, actively monitored (Tab. III), and effectively treated in every patient with acromegaly. Given the likelihood of cardiovascular complications, blood pressure should be measured during every examination of a patient with acromegaly, while electrocardiographic and echocardiographic examinations should be performed once a year. Bearing in mind the most common respiratory complications, polysomnography is recommended. Due to frequent metabolic and hormonal complica- 
tions, one should rule out disorders of carbohydrate, lipid, and calcium/phosphorus metabolism, as well as thyroid or gonadal dysfunction. Because patients with acromegaly are predisposed to neoplasms, hyperplasia of the large intestine and thyroid should first be ruled out $[4,42]$. Detailed propositions for the monitoring of acromegaly complications are presented in Table III [1].

In patient monitoring, in addition to normalisation of hormone levels, increasing importance is attached to the assessment of the quality of life (AcroQoL questionnaire) [43] and the disease course on the basis of two questionnaires: SAGIT (Signs and symptoms, Associated co-morbidities, GH levels, IGF-1 levels, Tumour profile) [44] and ACRODAT (Acromegaly Disease Activity Tool) [45].

Pharmacoeconomic analyses show that long-term pharmacological treatment of the disease and its complications is associated with the highest financial burden [46]. Every way of reducing pharmacotherapy costs (cure with surgical treatment or radiotherapy, pharmacotherapy optimisation by dose reduction, or extension of dosage intervals while biochemical control of the disease is maintained) brings tangible financial benefits related to prolonged survival of effectively treated patients with acromegaly [25, 46, 47].

\section{Prognosis}

Untreated acromegaly shortens survival by approximately 10 years. The risk of premature death in a patient with active acromegaly is twice as high. Cardiovascular complications $(60 \%)$, respiratory complications $(25 \%)$, and neoplasms $(15 \%)$ are the most common causes of death. GH secretion of less than $2.5 \mu \mathrm{g} / \mathrm{L}$ and normalisation of IGF-1 secretion restore normal life expectancy $[10,48]$.

The most recent reports say that life expectancy can indeed be restored in effectively treated patients with acromegaly $[47,49]$. This takes place in countries where early diagnostic evaluation and advanced therapies are more accessible. As the survival of patients with acromegaly increases, neoplasms are becoming a more common cause of death. Therefore, early anticancer prevention and diagnostic assessment for the most common cancers as in the general population are required $[47,50]$.

\section{Summary}

Acromegaly is a rare chronic disease caused by excessive production of GH by the pituitary tumour. Even though it leads to characteristic changes in the appearance and the development of multiple systemic complications, its diagnosis is delayed. Late diagnosis of acromegaly results in cardiovascular and respiratory complications as well as malignancies. They are responsible for approximately $30 \%$ higher mortality in untreated patients as compared with the general population.

In our country, primary care physicians play a major role in improved diagnosis of acromegaly. When seeing patients with hypertension, heart failure, diabetes, and osteoarticular ailments that are not age-specific, they should look out for somatic features of acromegaly, and if such features are found, they should order a screening IGF-1 assay. The diagnosis of active acromegaly is established when the GH level is not suppressed below $1.0 \mu \mathrm{g} / \mathrm{L}$ (or below $0.4 \mu \mathrm{g} / \mathrm{L}$ in an ultrasensitive GH assay) in OGTT and a pituitary tumour has been found on MRI. It is recommended that these tests and examinations be performed at reference centres, where assessment for complications should be carried out and a treatment plan should be worked out.

Patients who have a chance of cure with surgical removal of the pituitary tumour should be referred to centres specialising in this type of procedures, after pharmacological preparation with somatostatin analogues. Other patients, as well as those who failed to achieve cure with surgery, should receive chronic treatment with first-generation long-acting somatostatin analogues. Pasireotide, pegvisomant, or cabergoline may be used as alternative treatment options. In every case, in addition to assessing treatment effectiveness, one should monitor the course of acromegaly complications and actively treat them. Patient management needs to be individualised depending on the disease stage, tumour size and location, co-morbidities, as well as the patient's age and preferences.

Knowledge of the course of acromegaly should be systematically updated and supplemented with the experience of Polish healthcare providers, which is why participation in creating the Acromegaly Registry should be encouraged (www.acromegaly.pl).

\section{Author contributions}

The names of first three authors - M.B., M.R., W.Z. - are given in the alphabetical order, the first authorship is of equal rank.

\section{References}

1. Bolanowski M, Ruchała M, Zgliczyński W, et al. Acromegaly - a novel view of the patient. Polish proposals for diagnostic and therapeutic procedures in the light of recent reports. Endokrynol Pol. 2014; 65(4): 326-331, doi: 10.5603/EP.2014.0045, indexed in Pubmed: 25185857.

2. Giustina A, Bronstein MD, Casanueva FF, et al. Current management practices for acromegaly: an international survey. Pituitary. 2011; 14(2): 125-133, doi: 10.1007/s11102-010-0269-9, indexed in Pubmed: 21063787. 
3. Katznelson L, Laws ER, Melmed S, et al. Endocrine Society. Acromeg aly: an endocrine society clinical practice guideline. J Clin Endocrino Metab. 2014; 99(11): 3933-3951, doi: 10.1210/jc.2014-2700, indexed in Pubmed: 25356808.

4. Melmed S, Casanueva FF, Klibanski A, et al. Pituitary Society and the European Neuroendocrine Association. A consensus on the diagnosis and treatment of acromegaly complications. Pituitary. 2013; 16(3): 294-302, doi: 10.1007/s11102-012-0420-x, indexed in Pubmed: 22903574

5. Melmed S, Bronstein MD, Chanson P, et al. A Consensus Statement on acromegaly therapeutic outcomes. Nat Rev Endocrinol. 2018; 14(9): 552-561, doi: 10.1038/s41574-018-0058-5, indexed in Pubmed: 30050156.

6. Paragliola RM, Salvatori R. Novel somatostatin receptor ligands therapies for acromegaly. Front Endocrinol (Lausanne). 2018; 9: 78, doi: 10.3389/fendo.2018.00078, indexed in Pubmed: 29563895.

7. Chanson P, Salenave S, Kamenicky P. Pituitary tumours: acromegaly. Best Pract Res Clin Endocrinol Metab. 2009; 23(5): 555-574, doi: 10.1016/j beem.2009.05.010, indexed in Pubmed: 19945023.

8. Melmed S. Medical progress: acromegaly. N Engl J Med. 2006; 355(24): 2558-2573, doi: 10.1056/NEJMra062453, indexed in Pubmed: 17167139

9. Reid TJ, Post KD, Bruce JN, et al. Features at diagnosis of 324 patients with acromegaly did not change from 1981 to 2006: acromegaly remains under-recognized and under-diagnosed. Clin Endocrinol (Oxf). 2010; 72(2): 203-208, doi: 10.1111/j.1365-2265.2009.03626.x, indexed in Pubmed: 19473180.

10. Holdaway IM, Rajasoorya C. Epidemiology of acromegaly. Pituitary. 1999; 2(1): 29-41, indexed in Pubmed: 11081170.

11. Orlewska E, Kos-Kudła B, Sowiński J, et al. Wyniki fazy retrospektywnej badania obserwacyjnego Lanro-Study oceniajacego zużycie zasobów ochrony zdrowia $\mathrm{w}$ populacji polskich pacjentów z akromegalią, leczonych preparatem Somatuline AUTOGEL [Results of the retrospective phase of an observational study Lanro-Study evaluating the use of health care resources in the population of Polish patients with acromegaly, treated with Somatuline Autogel]. Nowa Medycyna. 2012; 3: 39-46.

12. Fernandez A, Karavitaki N, Wass JAH. Prevalence of pituitary adenomas: a community-based, cross-sectional study in Banbury (Oxfordshire, UK). Clin Endocrinol (Oxf). 2010; 72(3): 377-382, doi: 10.1111/j.1365-2265.200 9.03667.x, indexed in Pubmed: 19650784.

13. Beckers A, Lodish MB, Trivellin G, et al. X-linked acrogigantism syndrome: clinical profile and therapeutic responses. Endocr Relat Cancer. 2015; 22(3): 353-367, doi: 10.1530/ERC-15-0038, indexed in Pubmed: 25712922.

14. Stelmachowska-Banas M, Zgliczynski W, Tutka P, et al. Fatal Carney Complex in Siblings Due to De Novo Large Gene Deletion. J Clin Endocrinol Metab. 2017; 102(11): 3924-3927, doi: 10.1210/jc.2017-01045, indexed in Pubmed: 28973408.

15. Bernabeu I, Aller J, Álvarez-Escolá C, et al. Criteria for diagnosis and postoperative control of acromegaly, and screening and management of it comorbidities: Expert consensus. Endocrinol Diabetes Nutr. 2018; 65(5): 297-305, doi: 10.1016/j.endinu.2018.01.008, indexed in Pubmed: 29653911.

16. Potorac I, Petrossians P, Daly AF, et al. T2-weighted MRI signal predicts hormone and tumor responses to somatostatin analogs in acromegaly. Endocr Relat Cancer. 2016; 23(11): 871-881, doi: 10.1530/ERC-16-0356, indexed in Pubmed: 27649724.

17. Giustina A, Chanson P, Kleinberg D, et al. Acromegaly Consensus Group. Expert consensus document: A consensus on the medical treatment of acromegaly. Nat Rev Endocrinol. 2014; 10(4): 243-248, doi: 10.1038/nrendo.2014.21, indexed in Pubmed: 24566817

18. Bolanowski M, Bar-Andziak E, Kos-Kudła B, et al. Polish Society for Endocrinology. Consensus statement of the Polish Society for Endocrinology: presurgical somatostatin analogs therapy in acromegaly. Neuro Endocrinol Lett. 2008; 29(1):59-62, indexed in Pubmed: 18283267.

19. Annamalai AK, Webb A, Kandasamy N, et al. A comprehensive study of clinical, biochemical, radiological, vascular, cardiac, and sleep parameters in an unselected cohort of patients with acromegaly undergoing presurgical somatostatin receptor ligand therapy. J Clin Endocrinol Metab. 2013; 98(3): 1040-1050, doi: 10.1210/jc.2012-3072, indexed in Pubmed: 23393175.

20. Bates PR, Carson MN, Trainer PJ, et al. UK National Acromegaly Register Study Group (UKAR-2). Wide variation in surgical outcomes for acromegaly in the UK. Clin Endocrinol (Oxf). 2008; 68(1): 136-142, doi: 10.1 111/j.1365-2265.2007.03012.x, indexed in Pubmed: 17803712

21. Colao A, Attanasio R, Pivonello R, et al. Partial surgical removal of growth hormone-secreting pituitary tumors enhances the response to somatostatin analogs in acromegaly. J Clin Endocrinol Metab. 2006; 91(1): 85-92, doi: 10.1210/jc.2005-1208, indexed in Pubmed: 16263832.

22. Schopohl J, Strasburger CI, Caird D, et al. German Lanreotide Study Group. Efficacy and acceptability of lanreotide Autogel ${ }^{\circledR} 120 \mathrm{mg}$ at different dose intervals in patients with acromegaly previously treated with octreotide LAR. Exp Clin Endocrinol Diabetes. 2011; 119(3): 156-162 doi: 10.1055/s-0030-1267244, indexed in Pubmed: 21086246

23. Colao A, Pivonello R, Auriemma RS, et al. Beneficial effect of dose escalation of octreotide-LAR as first-line therapy in patients with acromegaly.
Eur J Endocrinol. 2007; 157(5): 579-587, doi: 10.1530/EJE-07-0383, indexed in Pubmed: 17984237.

24. Murray RD, Melmed S. A critical analysis of clinically available somatostatin analog formulations for therapy of acromegaly. I Clin Endocrinol Metab. 2008; 93(8): 2957-2968, doi: 10.1210/jc.2008-0027, indexed in Pubmed: 18477663.

25. Gomez-Panzani E, Chang S, Ramis J. Sustained biochemical control in patients with acromegaly treated with lanreotide depot $120 \mathrm{mg}$ administered every 4 weeks, or an extended dosing interval of 6 or 8 weeks: a pharmacokinetic approach. Res Rep Endocrine Dis. 2012; 2: 79-84, doi: 10.2147/RRED.S38149.

26. Witek P, Mucha S, Ruchała M. Patient satisfaction and preferences of lanreotide Autogel treatment in acromegaly. Endokryno Pol. 2016; 67(6): 572-579, doi: 10.5603/EP.2016.0066, indexed in Pubmed: 28042650

27. Cuevas-Ramos D, Fleseriu M. Somatostatin receptor ligands and resistance to treatment in pituitary adenomas. J Mol Endocrinol. 2014; 52(3): R223-R240, doi: 10.1530/JME-14-0011, indexed in Pubmed: 24647046.

28. Colao A, Bronstein MD, Freda P, et al. Pasireotide C2305 Study Group. Pasireotide versus octreotide in acromegaly: a head-to-head superiority study. J Clin Endocrinol Metab. 2014; 99(3): 791-799, doi: 10.1210/jc.2013-2480, indexed in Pubmed: 24423324.

29. Gadelha MR, Bronstein MD, Brue T, et al. Pasireotide C2402 Study Group. Pasireotide versus continued treatment with octreotide or lanreotide in patients with inadequately controlled acromegaly (PAOLA): a randomised, phase 3 trial. Lancet Diabetes Endocrinol. 2014; 2(11): 875-884, doi: 10.1016/S2213-8587(14)70169-X, indexed in Pubmed: 25260838.

30. Muhammad A, Van der Lely AJ, Delhanty P, et al. Efficacy and Safety of Switching to Pasireotide in Patients With Acromegaly Controlled With Pegvisomant and First-Generation Somatostatin Analogues (PAPE Study). J Clin Endocrinol Metab. 2018; 103(2): 586-595, doi: 10.1210/jc.2017-02017, indexed in Pubmed: 29155991.

31. Shimon I, Adnan Z, Gorshtein A, et al. Efficacy and safety of long-acting pasireotide in patients with somatostatin-resistan acromegaly: a multicenter study. Endocrine. 2018; 62(2): 448-455, doi: 10.1007/s12020-018-1690-5, indexed in Pubmed: 30051198.

32. Leonart LP, Tonin FS, Ferreira VL, et al. Effectiveness and safety of pegvisomant: a systematic review and meta-analysis of observational longitudinal studies. Endocrine. 2018 [Epub ahead of print], doi: 10.1007/s12020-018-1729-7, indexed in Pubmed: 30145746.

33. Buchfelder $\mathrm{M}$, van der Lely AJ, Biller BMK, et al. Long-term treatment with pegvisomant: observations from 2090 acromegaly patients in ACROSTUDY. Eur J Endocrinol. 2018; 179(6): 419-427, doi: 10.1530/EJE-18-0616, indexed in Pubmed: 30325178

34. Strasburger CJ, Mattsson A, Wilton P, et al. Increasing frequency of combination medical therapy in the treatment of acromegaly with the GH receptor antagonist pegvisomant. Eur J Endocrinol. 2018; 178(4): 321-329, doi: 10.1530/EJE-17-0996, indexed in Pubmed: 29371335.

35. Ramos-Leví AM, Bernabeu I, Álvarez-Escolá C, et al. Long-term treatment with pegvisomant for acromegaly: a 10-year experience. Clin Endocrinol (Oxf). 2016; 84(4): 540-550, doi: 10.1111/cen.12993, indexed in Pubmed: 26662620.

36. Kuhn E, Chanson P. Cabergoline in acromegaly. Pituitary. 2017; 20(1): 121-128, doi: 10.1007/s11102-016-0782-6, indexed in Pubmed: 28025719.

37. Sandret L, Maison P, Chanson P. Place of cabergoline in acromegaly: a meta-analysis. J Clin Endocrinol Metab. 2011; 96(5): 1327-1335, doi: 10.1210/jc.2010-2443, indexed in Pubmed: 21325455.

38. Lim DS, Fleseriu M. The role of combination medical therapy in the treatment of acromegaly. Pituitary. 2017; 20(1): 136-148, doi: 10.1007/s11102-016-0737-y, indexed in Pubmed: 27522663.

39. Wass JAH. Radiotherapy in acromegaly: a protagonists viewpoint. Clin Endocrinol (Oxf) 2003. 58(2): 128-131, indexed in Pubmed: 12580924

40. Thorner MO. Controversy: radiotherapy for acromegaly. Clin Endocrinol (Oxf). 2003; 58(2): 136-137, indexed in Pubmed: 12580926.

41. Casanueva FF, Barkan AL, Buchfelder M, et al. Pituitary Society, Expert Group on Pituitary Tumors, Pituitary Society, Expert Group on Pituitary Tumors. Criteria for the definition of Pituitary Tumor Centers of Excellence (PTCOE): A Pituitary Society Statement. Pituitary. 2017; 20(5): 489-498, doi: 10.1007/s11102-017-0838-2, indexed in Pubmed: 28884415

42. Woliński K, Stangierski A, Gurgul E, et al. Thyroid lesions in patients with acromegaly - case-control study and update to the meta-analysis. Endokrynol Pol. 2017; 68(1): 2-6, doi: 10.5603/EP.2017.0001, indexed in Pubmed: 28255974

43. Webb SM. Quality of life in acromegaly. Neuroendocrinology. 2006; 83(3-4): 224-229, doi: 10.1159/000095532, indexed in Pubmed: 17047387.

44. Giustina A, Bevan JS, Bronstein MD, et al. SAGIT Investigator Group. SAGIT ${ }^{\circledR}$ : clinician-reported outcome instrument for managing acromegaly in clinical practice--development and results from a pilot study. Pituitary. 2016; 19(1): 39-49, doi: 10.1007/s11102-015-0681-2, indexed in Pubmed: 26377024.

45. van der Lely AJ, Gomez R, Pleil A, et al. Development of ACRODAT, a new software medical device to assess disease activity in patients with acro- 
megaly. Pituitary. 2017; 20(6): 692-701, doi: 10.1007/s11102-017-0835-5, indexed in Pubmed: 28887782.

46. Elbaum M, Mizera $€$, Bolanowski M. Real costs of acromegaly: analysis of different therapies. Endokrynol Pol. 2018; 70(1): 74-79, doi: 10.5603/EP.a2018.0080.

47. Neggers SJ, Pronin V, Balcere I, et al. LEAD Study Group. Lanreotide Autogel $120 \mathrm{mg}$ at extended dosing intervals in patients with acromegaly biochemically controlled with octreotide LAR: the LEAD study. Eur J Endocrinol. 2015; 173(3): 313-323, doi: 10.1530/EJE-15-0215, indexed in Pubmed: 26047625.
48. Bolfi F, Neves AF, Boguszewski CL, et al. Mortality in acromegaly decreased in the last decade: a systematic review and meta-analysis. Eur J Endocrinol. 2018; 179(1): 59-71, doi: 10.1530/EJE-18-0255, indexed in Pubmed: 29764907.

49. Gadelha MR, Kasuki L, Lim DSt, et al. Systemic complications of acromegaly and the impact of the current treatment landscape: an update. Endocr Rev. 2018 [Epub ahead of print], doi: 10.1210/er.2018-00115, indexed in Pubmed: 30184064.

50. Dekkers OM, Biermasz NR, Pereira AM, et al. Mortality in acromegaly: a metaanalysis. J Clin Endocrinol Metab. 2008; 93(1): 61-67, doi: 10.1210/jc.2007-1191, indexed in Pubmed: 17971431. 


\title{
Rozpoznanie i leczenie akromegalii — aktualizacja rekomendacji Polskiego Towarzystwa Endokrynologicznego
}

\author{
Marek Bolanowski', Marek Ruchała², Wojciech Zgliczyński³ , Beata Kos-Kudła ${ }^{4}$, \\ Alicja Hubalewska-Dydejczyk', Andrzej Lewiński ${ }^{6}$
}

${ }^{1}$ Katedra i Klinika Endokrynologii, Diabetologii i Leczenia Izotopami, Uniwersytet Medyczny im. Piastów Śląskich we Wrocławiu ${ }^{2}$ Katedra i Klinika Endokrynologii, Przemiany Materii i Chorób Wewnętrznych, Uniwersytet Medyczny im. Karola

Marcinkowskiego w Poznaniu

${ }^{3}$ Klinika Endokrynologii, Centrum Medyczne Kształcenia Podyplomowego w Warszawie

${ }^{4}$ Klinika Endokrynologii, Katedra Patofizjologii i Endokrynologii, Ślaski Uniwersytet Medyczny w Katowicach

${ }^{5}$ Katedra i Klinika Endokrynologii, Uniwersytet Jagielloński, Collegium Medicum w Krakowie

${ }^{6}$ Katedra i Klinika Endokrynologii i Chorób Metabolicznych, Uniwersytet Medyczny w Łodzi

Artykuł jest tłumaczeniem pracy: Marek Bolanowski, Marek Ruchała, Wojciech Zgliczyński, Beata Kos-Kudła,

Alicja Hubalewska-Dydejczyk, Andrzej Lewiński. Diagnostics and treatment of acromegaly - updated recommendations

of the Polish Society of Endocrinology. Endokrynol Pol 2019; 70 (1): 2-10.

Należy cytować wersję pierwotną.

Piśmiennictwo dostępne w wersji pierwotnej na stronach 8-10.

\begin{abstract}
Streszczenie
Akromegalia jest rzadką chorobą spowodowaną nadmiernym wydzielaniem hormonu wzrostu (GH), zwykle przez guz przysadki. Rozpoznanie jest zwykle stawiane z opóźnieniem, w związku z czym często dochodzi do rozwoju różnych powikłań choroby będących przyczyną zwiększonego zagrożenia zgonem. U chorych z nadciśnieniem, niewydolnością serca, cukrzycą, artropatiami, nietypowymi dla wieku, należy zwrócić uwagę na występowanie objawów akromegalii. Oznaczanie stężenia insulinopodobnego czynnika wzrostu 1 (IGF-1) powinno być stosowane jako badanie przesiewowe przy podejrzeniu akromegalii. Dalsza diagnostyka i leczenie powinny być prowadzone w wyspecjalizowanych ośrodkach. Leczeniem pierwszego rzutu jest wybiórcze usunięcie gruczolaka przysadki z dostępu przez zatokę klinową. Pacjentów, u których jest szansa na wyleczenie w wyniku operacyjnego usunięcia guza przysadki, po przygotowaniu farmakologicznym należy kierować do ośrodków mających doświadczenie w tego typu zabiegach. U pozostałych chorych oraz u pacjentów, u których leczenie neurochirurgiczne było nieskuteczne, należy stosować przewlekłe leczenie, w pierwszej kolejności analogami somatostatyny pierwszej generacji. W leczeniu drugiego rzutu należy rozważyć pazyreotyd, pegwisomant, kabergolinę lub ich kombinacje. W każdym przypadku chorych należy objąć obserwacją przez całe życie w celu monitorowania i aktywnego leczenia następstw akromegalii. Obecne zalecenia są uaktualnioną wersją rekomendacji publikowanych w Endokrynologii Polskiej w 2014 roku. Uwzględniają one krajowe realia i powinny być pomocne w postępowaniu z pacjentami chorymi na akromegalię.
\end{abstract}

Słowa kluczowe: akromegalia; diagnostyka; leczenie; zalecenia

\section{Wprowadzenie}

Polskie propozycje postępowania diagnostyczno-terapeutycznego $\mathrm{w}$ akromegalii po raz pierwszy opublikowano w 2014 r. [1]. Nawiązywały one do postępujących zmian kryteriów rozpoznawania, wyleczenia i kontroli farmakologicznej choroby, a także nowych możliwości terapeutycznych [2,3]. Zwracały także szczególną uwagę na rozwój powikłań akromegalii wpływających negatywnie na długość i jakość życia pacjentów [4]. Od tego czasu osiągnięto dalszy postęp w diagnostyce i zwiększyła się dostępność różnych form farmakoterapii, w związku z czym pojawiła się potrzeba uaktualnienia zaleceń i dostosowania ich do nowych możliwości terapii, z uwzględnieniem krajowej specyfiki $[5,6]$.

\section{Charakterystyka choroby}

Akromegalia jest rzadką, przewlekłą chorobą spowodowaną nadmiernym wydzielaniem hormonu wzrostu (GH, growth hormone), najczęściej przez guz przysadki. Prowadzi do zmian wyglądu zewnętrznego z powiększeniem twarzoczaszki, rąk i stóp, rozrostu tkanek miękkich, kości i narządów wewnętrznych oraz wielu powikłań układowych, które są przyczyną pogorszenia jakości życia i jego skrócenia [7-9]. Objawy akromegalii zestawiono $\mathrm{w}$ tabeli I [1]. 
Tabela I. Objawy kliniczne akromegalii [1]

\begin{tabular}{|c|c|}
\hline \multirow[t]{8}{*}{ Objawy ogólne } & $\begin{array}{l}\text { Powiększenie: rąk, stóp, twarzoczaszki (nos, } \\
\text { żuchwa, zatoki czołowe), języka }\end{array}$ \\
\hline & Pogrubienie rysów twarzy \\
\hline & Obrzmienie tkanek miękkich \\
\hline & Powiększenie narządów wewnętrznych \\
\hline & Przyrost masy ciała \\
\hline & Wzmożona potliwość \\
\hline & Nadmierne owłosienie \\
\hline & Zmiana barwy głosu \\
\hline \multirow[t]{3}{*}{ Układ krążenia } & Nadciśnienie tętnicze \\
\hline & Duszność, obrzęki (niewydolność serca) \\
\hline & Zaburzenia rytmu serca \\
\hline \multirow{2}{*}{$\begin{array}{l}\text { Układ } \\
\text { oddechowy }\end{array}$} & Obturacyjny bezdech w czasie snu, chrapanie \\
\hline & $\begin{array}{l}\text { Upośledzona drożność górnych dróg } \\
\text { oddechowych }\end{array}$ \\
\hline \multirow{4}{*}{$\begin{array}{l}\text { Układ } \\
\text { hormonalny }\end{array}$} & Nietolerancja glukozy/cukrzyca \\
\hline & Wole, zaburzenia czynności tarczycy \\
\hline & Mlekotok \\
\hline & Możliwość guzów innych gruczołów (zespół MEN) \\
\hline \multirow[t]{2}{*}{$\begin{array}{l}\text { Układ } \\
\text { pokarmowy }\end{array}$} & $\begin{array}{l}\text { Zaparcia, możliwe wydłużenie i poszerzenie jelita } \\
\text { grubego (megakolon) }\end{array}$ \\
\hline & $\begin{array}{l}\text { Bóle brzucha, krew w kale (polipy i uchyłki jelita } \\
\text { grubego) }\end{array}$ \\
\hline \multirow{4}{*}{$\begin{array}{l}\text { Układ } \\
\text { moczowo- } \\
\text {-płciowy }\end{array}$} & Zaburzenia miesiączkowania \\
\hline & Obniżenie libido \\
\hline & Zaburzenia erekcji (hipogonadyzm) \\
\hline & $\begin{array}{l}\text { Kolka nerkowa (hiperkalciuria, nadczynność } \\
\text { przytarczyc - MEN) }\end{array}$ \\
\hline \multirow{3}{*}{$\begin{array}{l}\text { Układ } \\
\text { nerwowy }\end{array}$} & Bóle głowy \\
\hline & $\begin{array}{l}\text { Upośledzenie pola widzenia (makrogruczolak } \\
\text { może uciskać skrzyżowanie nerwów } \\
\text { wzrokowych) }\end{array}$ \\
\hline & Parestezje, niedowłady (zespół cieśni nadgarstka) \\
\hline \multirow{2}{*}{$\begin{array}{l}\text { Układ kostno- } \\
\text {-stawowy }\end{array}$} & Bóle i deformacje kości i stawów \\
\hline & Ograniczona ruchomość stawów \\
\hline
\end{tabular}

\section{Epidemiologia}

Częstość występowania akromegalii szacuje się na około 70 przypadków na 1 mln osób. Rocznie stwierdza się około 3-4 nowe zachorowania na 1 mln osób. Szacunkowo w Polsce na to schorzenie może cierpieć nawet około 3000 chorych. Akromegalię stwierdza się ze zbliżoną częstością u obu płci, najczęściej u osób w 4.-6. dekadzie życia. Przeważnie rozpoznanie choroby następuje dopiero po 5-10 latach od pojawienia się jej pierwszych objawów, zazwyczaj wcześniej u kobiet niż u mężczyzn [7-11]. Wyniki szczegółowych badań populacyjnych przeprowadzonych w ostatnich latach sugerują znacznie częstsze występowanie akromegalii niż dotychczas sądzono [12]. W związku z tym należy aktywnie poszukiwać choroby, szczególnie w grupie mężczyzn oraz osób z zaburzeniami układu sercowo-naczyniowego i kostno-stawowego, nieadekwat-
Tabela II. Powikłania akromegalii [1]

\begin{tabular}{ll}
\hline $\begin{array}{l}\text { Choroby układu } \\
\text { krążenia }\end{array}$ & Nadciśnienie tętnicze (do 60\%) \\
& Przerost serca (do 90\%) \\
& Zaburzenia rytmu serca (do 40\%) \\
& Wady zastawkowe serca (do 80\%) \\
& Niewydolność serca (do 10\%) \\
& Choroba niedokrwienna serca (do 40\%) \\
& Nagła śmierć sercowa \\
& Udar mózgu \\
\hline Choroby układu & Obturacyjny bezdech podczas snu (do 80\%) \\
oddechowego & Obturacja górnych dróg oddechowych \\
& Rozstrzenie oskrzeli \\
& Rozedma płuc \\
\hline Nowotwory & Złośliwe - jelita grubego (2\%), tarczycy (5\%), \\
& sutka i stercza \\
& tagodne - guzy tarczycy (do 90\%), polipy jelita \\
& grubego, mięśniaki macicy, tagodny rozrost \\
& stercza \\
\hline Zaburzenia & Hiperinsulinemia (do 80\%) \\
metaboliczne & Nietolerancja glukozy (do 40\%) \\
i hormonalne & Cukrzyca (do 20\%) \\
& Hiperlipidemia \\
& Hiperkalciuria (do 70\%) \\
& Hipogonadyzm (do 50\%) \\
Hipertyreoza (do 15\%) \\
\hline Choroby & Zmiany zwyrodnieniowo-wytwórcze (do 70\%) \\
Obładu kostno- & Obniżona gęstość mineralna kości (osteoporoza) \\
-stawowego & Złamania kręgów \\
\hline nerwowego & $\begin{array}{l}\text { Zaburzenia pola widzenia } \\
\text { Neuropatie }\end{array}$ \\
& Zespół cieśni nadgarstka (do 50\%) \\
\hline &
\end{tabular}

nymi do wieku [1]. Wczesne rozpoznanie umożliwia operacyjne wyleczenie choroby, stwarzając szansę przywrócenia oczekiwanej długości życia zbliżonej do populacyjnej i poprawy jego jakości.

\section{Patogeneza}

Guzy przysadki wydzielające GH (somatotropino$m a)$, będące przyczyną akromegalii, są łagodnymi gruczolakami. Zazwyczaj występują sporadycznie, jedynie 5-7\% powstaje na podłożu mutacji zarodkowej i może występować rodzinnie jako izolowane rodzinne gruczolaki przysadki (FIPA, familial isolated pituitary adenoma), zespół mnogich nowotworów wewnątrzwydzielniczych MEN typ 1 i typ 4, kompleks Carneya, gruczolak przysadki współwystępujący $\mathrm{z}$ pheochromocytoma/paraganglioma (3Pas, pituitary adenoma with paraganglioma/pheochromocytoma) czy też akrogigantyzmem związanym z chromosomem X [13]. Częstość tych mutacji jest jednak znacznie większa u osób młodych. Sięga ona $25 \%$ i prowadzi z reguły do rozwoju gruczolaków inwazyjnych i opornych na leczenie farmakologiczne, wymagających bardziej 
agresywnego postępowania [14].W związku z tym badania genetyczne należy rozważyć szczególnie u młodych pacjentów.

W chwili rozpoznania choroby średnica gruczolaków zwykle przekracza $10 \mathrm{~mm}$, są one więc już makrogruczolakami, mogącymi prowadzić do ograniczenia pola widzenia oraz innych zaburzeń endokrynnych (niedoczynność przysadki, hiperprolaktynemia). Większość objawów choroby i jej powikłań (tab. I i II) wynika z nadmiernego działania insulinopodobnego czynnika wzrostu 1 (IGF-1, insulin-like growth factor 1) na tkanki, stymulowanego przez zwiększone wydzielanie GH [7, 8]. Zwykle nasilenie objawów klinicznych, powikłań ogólnoustrojowych i stężenie GH korelują dodatnio z wielkością guza oraz czasem utrzymywania się akromegalii. Dłuższy czas trwania nierozpoznanej i nieleczonej choroby sprzyja więc nasileniu objawów klinicznych, rozwojowi następstw metabolicznych oraz powikłań ogólnoustrojowych choroby i tym samym zmniejsza szanse całkowitego wyleczenia.

\section{Rozpoznanie}

Podstawą rozpoznania czynnej akromegalii jest obecność objawów klinicznych (tab. I) oraz stwierdzenie zwiększonego równocześnie wydzielania IGF-1 i GH. U tych pacjentów, u których na podstawie objawów klinicznych można podejrzewać akromegalię, należy przesiewowo oznaczyć stężenie IGF-1 (ryc. 1) [1]. W przypadku uzyskania wartości podwyższonych (dla wieku i płci) zaleca się przeprowadzenie testu hamowania wydzielania GH po doustnym podaniu 75 g glukozy (OGTT, oral glucose tolerance test). $\mathrm{U}$ chorych z rozpoznaną cukrzycą zamiast OGTT należy kilkakrotnie oznaczyć stężenie $\mathrm{GH}$, np. co 30 min przez 2-3 godziny. O czynnej akromegalii świadczy podwyższone stężenie IGF-1 oraz brak zahamowania wydzielania GH w OGTT poniżej 1,0 $\mu \mathrm{g} / \mathrm{l}(\mathrm{ng} / \mathrm{ml})$ lub poniżej $0,4 \mu \mathrm{g} / \mathrm{l}$ w przypadku stosowania ultraczułych oznaczeń GH $[1,5,6,15]$. Przypadkowy wynik stężenia GH poniżej $1,0 \mu \mathrm{g} / 1$ pozwala wykluczyć aktywną akromegalię [2, 3]. Stężenie GH w OGTT może być zależne od wieku pacjenta, wartości wskaźnika masy ciała (BMI, body mass index), płci i stosowania estrogenów, należy zatem uwzględnić te czynniki przy interpretacji testu. Przede wszystkim należy pamiętać, że fałszywie dodatni wynik stężenia GH może być efektem okresu dojrzewania, niedożywienia, doustnego stosowania estrogenów, a także niewydolności nerek lub wątroby, czy też nadczynności tarczycy. W okresie dojrzewania i w nadczynności tarczycy fałszywie podwyższone może być też stężenie IGF-1. W momencie rozpoznania choroby należy ocenić również obecność i stopień zaawansowania jej powikłań ogólnoustrojowych, zaburzeń metabolicznych i dysfunkcji hormonalnych związanych z obecnością guza przysadki (tab. II) [1].

W celu jednoznacznego określenia przyczyny akromegalii konieczne jest obrazowanie okolicy siodła tureckiego metodą rezonansu magnetycznego (MR, magnetic resonance) z użyciem kontrastu. W przypadku stwierdzenia makrogruczolaka przysadki należy ocenić pole widzenia. Nieuwidocznienie guza przysadki w badaniu MR nasuwa podejrzenie ektopowego wydzielania somatoliberyny (GHRH, growth hormone-releasing hormone) lub rzadziej GH przez nowotwór neuroendokrynny, najczęściej oskrzeli, grasicy lub trzustki [5]. W badaniu MR guza przysadki należy także ocenić intensywność sygnału T2-zależnego w stosunku do mózgowia. Hipointensywność sygnału gruczolaka jest związana z jego strukturą bogatoziarnistą, mniejszą inwazyjnością i większą gęstością receptorów somatostatyny typu 2, co pozwala przewidzieć większą skuteczność leczenia analogami somatostatyny pierwszej generacji w zakresie redukcji wielkości gruczolaka i normalizacji hormonalnej [16].

Wczesne rozpoznanie akromegalii (zazwyczaj mniejszy guz, mniej nasilone objawy kliniczne i powikłania choroby) zwiększa skuteczność leczenia (operacyjnego i farmakologicznego), obniża koszty opieki medycznej nad chorym i potencjalnie przeciwdziała skróceniu przeżycia chorego na akromegalię.

\section{Leczenie}

Podstawowym celem leczenia akromegalii jest normalizacja wydzielania GH i IGF-1, co wiąże się z przywróceniem oczekiwanej długości życia chorych i poprawą jego jakości. Celem drugorzędowym jest usunięcie lub istotne zmniejszenie masy guza przysadki, co powinno prowadzić do ograniczenia zaburzeń wynikających z jego ekspansji. Oba cele można osiągnąć, stosując leczenie operacyjne, farmakologiczne i rzadziej radioterapię $[5,8,17]$.

Przy wyborze terapii należy oszacować możliwość jej powikłań oraz uwzględnić stan i wolę pacjenta. Zasadniczym sposobem terapii akromegalii, mogącym doprowadzić do wyleczenia, jest leczenie operacyjne - wybiórcze usunięcie gruczolaka przysadki, w miarę możliwości z dojścia przez zatokę klinową, z zachowaniem czynności hormonalnej pozostałej części przysadki, a w przypadku pozaprzysadkowego źródła choroby - usunięcie guza neuroendokrynnego ektopowo wydzielającego GHRH. Skuteczność i powodzenie leczenia operacyjnego guzów somatotropowych przysadki zależą od: stężenia $\mathrm{GH}$, wielkości, lokalizacji i ekspansji guza oraz doświadczenia chirurga. W przypadku mikrogruczolaków sukces operacyjny (stężenie $\mathrm{GH}<1,0 \mu \mathrm{g} / \mathrm{l})$ uzyskuje się u około 70-90\% chorych, 


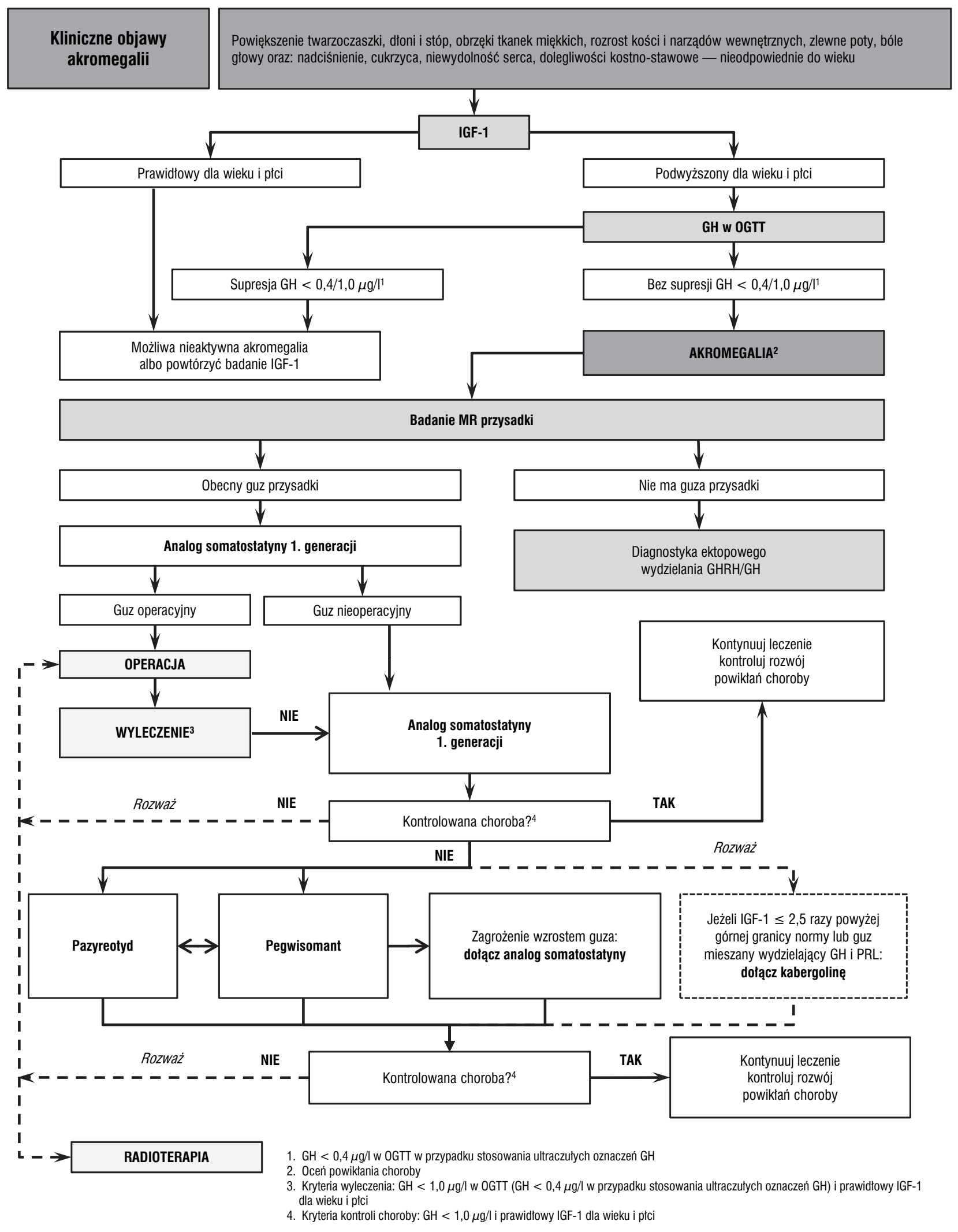

Rycina 1. Algorytm diagnostyki i leczenia akromegalii. IGF-1 — insulinopodobny czynnik wzrostu 1; GH - hormon wzrostu; OGTT — doustny test tolerancji glukozy; GHRH — somatoliberyna; PRL — prolaktyna 
natomiast $\mathrm{w}$ przypadku makrogruczolaków jedynie w około 30-50\% [17].

Oznacza to, że im większy jest guz, przebiegający dodatkowo z ekspansją pozasiodłową, tym skuteczność leczenia neurochirurgicznego jest mniejsza. Z tego powodu zgodnie z zaleceniami Polskiego Towarzystwa Endokrynologicznego należy rozważyć celowość przedoperacyjnego zastosowania analogów somatostatyny o przedłużonym działaniu, które ułatwiają leczenie operacyjne poprzez zmniejszenie objętości i zmianę konsystencji guza przysadki oraz poprawę stanu klinicznego pacjentów [18]. U leczonych dochodzi do zmniejszenia obrzęku tkanek miękkich (łatwiejsza intubacja), następuje poprawa w zakresie czynności układu sercowo-naczyniowego (zmniejszenie nadciśnienia tętniczego i stopnia niewydolności serca), obturacyjnego bezdechu sennego oraz parametrów zaburzeń metabolicznych [19]. Leczenie takie nie powinno jednak opóźniać postępowania operacyjnego, a jedynie do niego przygotowywać. Lepsze wyniki leczenia operacyjnego uzyskuje się w ośrodkach, w których wyspecjalizowany neurochirurg przeprowadza co najmniej 50 zabiegów przezklinowych rocznie, dlatego też odpowiednio przygotowanych chorych na operacje należy kierować do ośrodków wyspecjalizowanych $\mathrm{w}$ tego rodzaju zabiegach $[5,20]$.

Ze względu na to, że większoóć guzów w momencie rozpoznania akromegalii to makrogruczolaki, leczenie operacyjne często nie daje możliwości całkowitego wyleczenia dużej części chorych. Wówczas zaleca się zastosowanie farmakoterapii lub rzadziej — radioterapii. Usunięcie ponad 75\% masy guza zwiększa skuteczność pooperacyjnego leczenia analogami somatostatyny [21]. Alternatywą bądź uzupełnieniem leczenia operacyjnego somatotropowych gruczolaków przysadki jest farmakoterapia. Gruczolaki te wykazują ekspresję receptorów dla somatostatyny, a ligandy tego receptora - analogi somatostatyny (lanreotyd i oktreotyd) - normalizują wydzielanie GH u niespełna 50\% chorych $\mathrm{z}$ akromegalią, a u około połowy istotnie zmniejszają wielkość guza przysadki [5, 8].

W Polsce aktualnie dostępne są $\mathrm{w}$ farmakoterapii pierwszego rzutu akromegalii dwa analogi somatostatyny pierwszej generacji o przedłużonym działaniu:

- lanreotyd w postaci Autogel w ampułkach po 60, 90 i $120 \mathrm{mg}$ do podawania podskórnego co 28 dni z możliwością wydłużenia okresu między wstrzyknięciami do 56 dni w przypadku dawki $120 \mathrm{mg}[1,11,22]$;

— oktreotyd LAR w ampułkach po 10, 20 i 30 mg do podawania domięśniowego co 28 dni z możliwością zwiększenia dawki leku do $40 \mathrm{mg}$ co 4 tygodnie u pacjentów, u których dawka 30 mg jest nieskuteczna [23].
Dawkę analogu somatostatyny należy dostosować do uzyskanych efektów klinicznych i laboratoryjnych po 3 miesiącach podawania danego leku [5]. Pod względem skuteczności i tolerancji nie ma zasadniczych różnic między wymienionymi preparatami [24]. Leczenie nimi jest bezpieczne i z reguły dobrze tolerowane. Najczęstsze objawy niepożądane to ból brzucha, luźne stolce bądź biegunka. U około $20 \%$ leczonych może rozwinąć się kamica żółciowa, bardzo rzadko może wystąpić zapalenie trzustki [11].

Analogi somatostatyny, jak wcześniej wspomniano, powinny być stosowane przez kilka miesięcy jako przygotowanie do leczenia operacyjnego oraz jako terapia przewlekła $u$ chorych nieoperowanych oraz u tych, u których zabieg okazał się nieskuteczny. Leczenie to powinno być postępowaniem pierwszego wyboru u osób z istotnymi przeciwwskazaniami lub niewyrażających zgody na operację, oraz u chorych mających niewielkie szanse na wyleczenie lub poprawę kliniczną po zabiegu neurochirurgicznym (duże guzy z ekspansją pozasiodłową, przebiegające bez istotnego ucisku nerwów wzrokowych) [5].

Pacjenci z czynną akromegalią, po nieskutecznej operacji gruczolaka przysadki lub w oczekiwaniu na efekty radioterapii, jako leczenie uzupełniające winni stale przyjmować analogi somatostatyny o przedłużonym działaniu $w$ dawkach normalizujących stężenia GH i IGF-1 [3, 5, 17]. Możliwość zastosowania lanreotydu Autogel $120 \mathrm{mg}$ rzadziej niż co miesiąc (nawet co $56 \mathrm{dni}$ ) istotnie obniża koszty terapii oraz zwiększa komfort i jakość życia chorego [11, 22, 25, 26].

Czynnikami wpływającymi na skuteczność terapii analogami somatostatyny pierwszej generacji są: płeć (lepsza reakcja u kobiet), wiek $\mathrm{w}$ chwili rozpoznania (młodsi chorzy mają bardziej agresywne guzy), czas trwania choroby, wielkość gruczolaka i stopień wydzielania GH [27].

W przypadku nieskuteczności analogu somatostatyny pierwszej generacji $w$ terapii drugiego rzutu można zastosować analog somatostatyny nowej generacji o większym powinowactwie do receptorów somatostatyny typu 5 (pazyreotyd - dostępny w ramach programu lekowego) lub antagonistę receptora GH (pegwisomant $-\mathrm{w}$ trakcie procesu refundacyjnego w ramach programu lekowego). Inną możliwością jest dołączenie do analogu somatostatyny pierwszej generacji pegwisomantu podawanego jeden lub dwa razy w tygodniu albo agonisty dopaminy (ryc. 1) $[2,3,5,17]$.

Pazyreotyd ma silniejsze działanie od analogów somatostatyny pierwszej generacji, u większego odsetka pacjentów zmniejsza objętość guza oraz prowadzi do uzyskania kontroli biochemicznej lub dalszej, istotnej supresji stężeń GH i IGF-1. Wykazuje jednak działanie diabetogenne [27-31]. Istotnym elementem 
przed leczeniem i w trakcie terapii pazyreotydem jest odpowiednia kontrola gospodarki węglowodanowej. Pazyreotyd zaleca się w przypadku braku kontroli biochemicznej, przede wszystkim u pacjentów z zagrożeniem wzrostem guza i bez niekontrolowanych zaburzeń gospodarki węglowodanowej. Pazyreotyd o przedłużonym działaniu podaje się domięśniowo, w dawkach 20, 40 i 60 mg co 4 tygodnie [27-31]. Przez pierwsze 3 miesiące po włączeniu pazyreotydu należy monitorować stężenie glukozy we krwi co tydzień. Po zwiększeniu dawki podobna kontrola wymagana jest przez 4-6 tygodni. Z kolei pegwisomant lub kabergolina mogą być wskazane u pacjentów z niewielkim lub nieuwidocznionym w MR guzem przysadki, z niekontrolowaną cukrzycą (ryc. 1) [2, 3, 5].

Pegwisomant, blokujący działanie GH w tkankach docelowych, normalizuje stężenie IGF-1 u ponad 70\% leczonych, prowadząc tym samym do poprawy klinicznej i wyrównania zaburzeń metabolicznych (m.in. zwiększając insulinowrażliwość, poprawia metabolizm węglowodanów) [32, 33]. Ze względu na obwodowe działanie leku stężenie GH nie może służyć do oceny skuteczności terapii, jedyną jej miarą jest ocena stężenia IGF-1. Pegwisomant nie wpływa korzystnie na wielkość guza przysadki i z uwagi na ryzyko powiększania się gruczolaka w czasie leczenia konieczna jest kontrola jego objętości za pomocą MR. W przypadku powiększenia się gruczolaka można dodatkowo zastosować analog somatostatyny [34]. Pegwisomant podaje się codzienne, w dawkach 10-30 mg podskórnie w monoterapii lub łącznie $z$ analogiem somatostatyny [32, 34, 35].

Skuteczność agonistów dopaminy w leczeniu akromegalii jest mniejsza. Zalecane dawki tych leków w akromegalii zazwyczaj powinny być większe niż stosowane $\mathrm{w}$ gruczolakach przysadki wydzielających prolaktynę (PRL) - prolaktynoma [5, 36]. Dostępna w Polsce bromokryptyna normalizuje stężenie IGF-1 jedynie u $10 \%$ chorych na akromegalię i nie powinna być stosowana w tej chorobie [37]. Droższe w polskich warunkach (nierefundowane) leczenie kabergoliną prowadzi do normalizacji IGF-1 w około 35\% przypadków, największą korzyść odnoszą pacjenci z guzami mieszanymi, wydzielającymi GH i PRL. Kabergolina w skojarzeniu $\mathrm{z}$ analogami somatostatyny poprawia skuteczność ich działania u osób z opornością na maksymalne dawki analogów somatostatyny [36, 37]. Kabergolinę zaleca się u chorych, u których stężenie IGF-1 nie przekracza 2,5-krotności górnej granicy normy [5].

Zastosowanie temozolomidu jest możliwe w przypadku bardzo agresywnych guzów nieodpowiadających na żadną z powyższych form terapii lub potwierdzonej złośliwości guza [5, 38].

Dzięki coraz lepszym wynikom leczenia operacyjnego oraz dostępności skutecznych leków radioterapia jest leczeniem trzeciego rzutu [39, 40]. Radioterapię stereotaktyczną należy rozważać w przypadku nieskuteczności leczenia operacyjnego i farmakologicznego, pamiętając, że prowadzi ona do uzyskania normalizacji stężenia IGF-1 w ciągu 10 lat u około 40\% pacjentów oraz może wiązać się z powikłaniami. Najczęstsze z nich to niedoczynność przysadki (około $80 \%$ poddanych konwencjonalnej radioterapii), znacznie rzadziej może dojść do popromiennego uszkodzenia nerwów wzrokowych, zaburzeń krążenia mózgowego oraz powstania nowotworów wtórnych.

Dodatkowy problem stanowi leczenie powikłań akromegalii, głównie nadciśnienia tętniczego i niewydolności serca, zaburzeń gospodarki węglowodanowej oraz zmian zwyrodnieniowo-wytwórczych układu kostno-stawowego (pozostałe powikłania przedstawiono w tab. II) [1, 4]. Choroby te nie tylko prowadzą do pogorszenia jakości i skrócenia długości życia pacjentów, ale ich leczenie generuje dodatkowo znaczne koszty. Wczesne rozpoznanie akromegalii stwarza szansę operacyjnego wyleczenia choroby, co minimalizuje rozwój jej powikłań, zmniejszając tym samym koszty ponoszone na ich leczenie.

Docelowo należy dążyć do organizacji multidyscyplinarnych wyspecjalizowanych ośrodków leczenia guzów przysadki (Pituitary Tumors Centres of Excellence) umożliwiających nowoczesne i skuteczne leczenie chorych z guzami przysadki, w tym akromegalią [41].

\section{Obserwacja pacjentów}

U każdego pacjenta z akromegalią należy prowadzić kontrolę skuteczności leczenia i przebiegu powikłań choroby na podstawie oceny klinicznej, badań laboratoryjnych i obrazowych.

Skuteczność leczenia operacyjnego można ocenić badaniem stężenia GH wkrótce po zabiegu (1 tydzień), natomiast wiarygodną ocenę stężenia IGF-1 powinno przeprowadzić się dopiero po około 3 miesiącach od operacji. Kryterium wyleczenia jest prawidłowe dla płci i wieku stężenie IGF-1 oraz stężenie GH $<1,0 \mu \mathrm{g} / 1$ $(\mathrm{lub}<0,4 \mu \mathrm{g} / \mathrm{l})$ w OGTT $[1,2,5]$. Podczas długoterminowego monitorowania chorych celowe jest stosowanie tych samych zestawów laboratoryjnych [5]. W przypadku laboratoryjnego potwierdzenia operacyjnego wyleczenia akromegalii oraz braku klinicznych zaburzeń widzenia i czynności przysadki nie ma potrzeby wykonywania badania MR.

U pacjentów, u których nie uzyskano chirurgicznego wyleczenia, obrazowanie okolicy siodła tureckiego za pomocą MR należy przeprowadzić po 3-4 miesiącach od zabiegu, a u pacjentów poddanych farmakoterapii - po 6-12 miesiącach od jej rozpoczęcia. Następne kontrolne badania MR należy powtarzać co roku (wy- 
Tabela III. Ocena przebiegu powikłań akromegalii [1]

\begin{tabular}{ll}
\hline Badanie & Częstość oceny \\
\hline Ciśnienie krwi & $\begin{array}{l}\text { Co 3-6 miesięcy, częściej przy zmianie } \\
\text { leczenia hipotensyjnego }\end{array}$ \\
\hline EKG & Co rok \\
\hline EKG wysitkowe & W przypadku objawów stenokardialnych \\
\hline Echokardiografia & Co rok \\
\hline Polisomnografia & Co rok \\
\hline OGTT & W przypadku podejrzenia cukrzycy \\
\hline Glukoza na czczo & Co 6-12 miesięcy \\
\hline HbA ${ }_{1 c}$ & Co 6-12 miesięcy w przypadku cukrzycy \\
\hline Lipidogram & Co rok \\
\hline Ca; P & W przypadku objawów kamicy nerek \\
\hline TSH, fT4 & Co rok \\
\hline PRL, testosteron & Co rok \\
(mężczyźni) & \\
\hline PRL, LH, FSH, E2 & Co rok \\
(kobiety) & \\
\hline USG tarczycy & Co 1-2 lata \\
\hline Kolonoskopia & Co 2-3 lata \\
\hline DXA & Co 2-3 lata \\
(w hipogonadyzmie) & \\
\hline
\end{tabular}

EKG - elektrokardiografia; OGTT (oral glucose tolerance test) — doustny test tolerancji glukozy; $\mathrm{HbA}_{1 \mathrm{c}}$ — hemoglobina glikowana; $\mathrm{Ca}$ - wapń; $\mathrm{P}$ — fosfor, TSH (thyroid-stimulating hormone) - tyreotropina; fT4 (free thyroxine)

— wolna tyroksyna; PRL — prolaktyna; LH (luteinizing hormone) — hormon luteinizujący; FSH (follicle-stimulating hormone) — hormon folikulotropowy;

E2 - estradiol; USG — ultrasonografia; DXA (dual-energy X-ray absorptiometry)

— dwuwiązkowa absorbcjometria rentgenowska

jątek mogą stanowić guzy szybko rosnące). Oceniając skuteczność leczenia farmakologicznego, należy brać pod uwagę stan kliniczny chorego (łącznie z oceną pola widzenia i jakości życia) oraz wyniki oznaczeń stężenia IGF-1 i GH przeprowadzone w warunkach podstawowych (nie ma konieczności wykonywania OGTT). Przyjmuje się, że skuteczne leczenie farmakologiczne (kontrolujące przebieg choroby) to takie, które utrzymuje stężenie IGF-1 w normie dla płci i wieku oraz $\mathrm{GH}<1,0 \mu \mathrm{g} / 1[1,2,5]$.

Pod względem klinicznym u każdego chorego z akromegalią należy zidentyfikować powikłania choroby (tab. II), aktywnie monitorować ich przebieg (tab. III) oraz skutecznie je leczyć. Mając na uwadze powikłania ze strony układu sercowo-naczyniowego, podczas każdego badania chorego z akromegalią należy zmierzyć ciśnienie tętnicze, co rok wykonać badanie EKG i echokardiograficzne. Pamiętając o najczęstszych powikłaniach z zakresu układu oddechowego, wskazane jest badanie polisomnograficzne. Z powodu częstych powikłań metabolicznych i hormonalnych należy wykluczyć zaburzenia: gospodarki węglowodanowej, lipidowej i wapniowo-fosforanowej oraz czynności tarczycy i gonad. Ze względu na zwiększoną w akromegalii predyspozycję do nowotworzenia w pierwszej kolejności należy wykluczyć zmiany rozrostowe jelita grubego i tarczycy $[4,42]$. Szczegółowe propozycje monitorowania powikłań akromegalii przedstawiono w tabeli III [1].

W monitorowaniu pacjentów coraz większe znaczenie, poza wyrównaniem hormonalnym, przypisuje się ocenie jakości życia (kwestionariusz AcroQoL) [43], ocenie przebiegu choroby na podstawie kwestionariuszy SAGIT (Signs and symptoms, Associated comorbidities, GH levels, IGF-1 levels, Tumour profile) [44] i ACRODAT (Acromegaly Disease Activity Tool) [45].

$\mathrm{W}$ analizach farmakoekonomicznych największe obciążenie finansowe przynosi wieloletnie leczenie farmakologiczne choroby i jej powikłań [46]. Każda możliwość zmniejszenia kosztów farmakoterapii (wyleczenie w wyniku zabiegu operacyjnego lub radioterapii, optymalizacja farmakoterapii przez redukcję dawki lub wydłużenie odstępów między dawkami utrzymująca kontrolę biochemiczną choroby) dają wymierne korzyści finansowe $\mathrm{w}$ aspekcie wydłużenia życia skutecznie leczonych chorych na akromegalię [25, 46, 47].

\section{Rokowanie}

Nieleczona akromegalia powoduje skrócenie przeżycia średnio o około 10 lat. Ryzyko wcześniejszej śmierci u chorego na czynną akromegalię zwiększa się dwukrotnie. Najczęstszymi przyczynami zgonów są powikłania ze strony układu krążenia $(60 \%)$, układu oddechowego (25\%) i nowotwory (15\%). Obniżenie wydzielania $\mathrm{GH}<2,5 \mu \mathrm{g} / 1$ i normalizacja wydzielania IGF-1 wiążą się z przywróceniem oczekiwanej długości przeżycia u chorych [10, 48].

Najnowsze doniesienia wskazują na przywrócenie oczekiwanej długości życia u skutecznie leczonych pacjentów z akromegalią $[47,49]$. Obserwacji tych dokonano w krajach, w których dostęp do wczesnej diagnostyki i nowoczesnych metod terapii jest ułatwiony.

Warto przy tym podkreślić, że w miarę wydłużania się życia chorych na akromegalię przyczyną ich zgonów częściej będą choroby nowotworowe, stąd ważna jest wczesna profilaktyka przeciwnowotworowa i diagnostyka najczęstszych nowotworów podobnie jak w całej populacji $[47,50]$.

\section{Podsumowanie}

Akromegalia jest rzadką, przewlekłą chorobą spowodowaną nadmiernym wydzielaniem GH przez guz przysadki. Mimo że choroba ta prowadzi do charakterystycznych zmian wyglądu zewnętrznego i rozwoju 
licznych powikłań ogólnoustrojowych, jest rozpoznawana z dużym opóźnieniem. Późne rozpoznanie akromegalii jest przyczyną rozwoju powikłań m.in. z zakresu układu sercowo-naczyniowego, oddechowego i nowotworów złośliwych. Odpowiadają one za około 30-procentowy wzrost śmiertelności u nieleczonych chorych w porównaniu z populacją ogólną.

Dużą rolę w poprawie rozpoznawania akromegalii w polskich warunkach odgrywają lekarze pierwszego kontaktu. U swoich pacjentów z nadciśnieniem tętniczym, niewydolnością serca, cukrzycą, dolegliwościami kostno-stawowymi, występującymi nieadekwatnie do wieku, powinni oni zwracać uwagę na obecność somatycznych cech akromegalii, a przy ich stwierdzeniu — przesiewowo oznaczać stężenie IGF-1. Potwierdzeniem czynnej akromegalii jest wykazanie braku zahamowania wydzielania GH $<1,0 \mu \mathrm{g} / 1$ (lub poniżej $0,4 \mu \mathrm{g} / \mathrm{l}$ w przypadku stosowania ultraczułych oznaczeń GH) w OGTT oraz obecność guza przysadki w obrazowaniu za pomocą MR. Jest wskazane, aby badania przeprowadzano w ośrodkach referencyjnych, które powinny ocenić również powikłania choroby i ustalić plan leczenia.

Pacjentów, u których istnieje szansa na wyleczenie akromegalii w wyniku operacyjnego usunięcia guza przysadki, po farmakologicznym przygotowaniu analogami somatostatyny, należy kierować wyłącznie do ośrodków wyspecjalizowanych w tego rodzaju zabiegach. Pozostałych chorych oraz tych, u których leczenie operacyjne nie doprowadziło do wyleczenia, należy poddać przewlekłej farmakoterapii analogami somatostatyny pierwszej generacji o przedłużonym działaniu. Alternatywą może być terapia pazyreotydem, pegwisomantem lub kabergoliną. W każdym przypadku, poza oceną skuteczności terapii, należy kontrolować przebieg powikłań akromegalii i aktywnie je leczyć. Postępowanie terapeutyczne powinno być zindywidualizowane i uzależnione od zaawansowania choroby, wielkości i lokalizacji guza, towarzyszących chorób oraz wieku i preferencji pacjenta.

Wiedza na temat przebiegu akromegalii powinna być systematycznie aktualizowana i uzupełniana o lokalne doświadczenia polskich lekarzy, dlatego też należy zachęcać do współtworzenia Rejestru Chorych na Akromegalię (www.acromegaly.pl).

\section{Współautorstwo pracy}

Kolejność nazwisk trzech pierwszych autorów - M.B., M.R., W.Z. - podano alfabetycznie, pierwsze autorstwo równorzędne. 